\title{
Review
}

\section{Methodology for determination of radiostrontium in milk: a review}

\author{
Stéphane BRUN ${ }^{\mathrm{a} *}$, Yann KERGADALLAN ${ }^{\mathrm{b}}$, Bernadette BOURSIER ${ }^{\mathrm{a}}$, \\ Jean-Marc FREMY ${ }^{\mathrm{a}}$, Françoise JANIN ${ }^{\mathrm{a}}$ \\ a Laboratoire d'Étude et de Recherche sur l'Hygiène et la Qualité des Aliments de l'Agence Française \\ de Sécurité Sanitaire des Aliments, AFSSA/LERHQA/CEN-RAD, 10 rue Pierre Curie, \\ 94704 Maisons Alfort, France \\ b Service de Protection contre les Rayonnements du Commissariat à l'Énergie Atomique, \\ CEA/SACLAY/UGSP/SPR/SRSE, 91191 Gif sur Yvette Cedex, France
}

(Received 20 December 2000; accepted 24 May 2002)

\begin{abstract}
This paper presents a review on all available analytical methods for ${ }^{90} \mathrm{Sr}$ and ${ }^{89} \mathrm{Sr}$ determination in milk. Special attention was focused on the parameter of the performing time in order to assess the rapid measurement of milk contamination, especially in the case of emergency situations such as a nuclear plant accident. Preliminarily, a short description of the milk matrix and radiostrontium transfer from soil to milk and its derivatives is given. Then analytical procedures are examined step by step. ${ }^{90} \mathrm{Sr}$ and ${ }^{89} \mathrm{Sr}$ can be separately determined in less than 2 days by a rapid sample pretreatment and the use of a liquid scintillation detector.
\end{abstract}

\section{Strontium / radioactivity / analytical method / milk}

Résumé - Revue des méthodes de dosage du radiostrontium dans le lait. Cet article présente l'ensemble des méthodes analytiques disponibles pour le dosage du ${ }^{90} \mathrm{Sr}$ et du ${ }^{89} \mathrm{Sr}$ dans le lait. Cette étude attache une importance toute particulière à la durée d'analyse dans le but d'une estimation rapide de la contamination du lait telle qu'elle est rendue nécessaire dans le cas de situations d'urgences comme l'accident d'une centrale nucléaire. En préliminaires, une rapide description de la matrice lait et du transfert du radiostrontium du sol au lait et ses dérivés est donnée. Puis, les procédures analytiques sont examinées étape par étape. Les isotopes 90 et 89 du strontium peuvent être déterminés séparément en moins de 2 jours par un traitement rapide de l'échantillon et l'utilisation d'un détecteur à scintillation liquide.

\section{Strontium / radioactivité / méthode d'analyse / lait}

\section{INTRODUCTION}

${ }^{90} \mathrm{Sr}$ is one of the most hazardous components of radioactive fallout. It is pro- duced essentially by the ${ }^{235} \mathrm{U}$ and ${ }^{239} \mathrm{Pu}$ fission reaction, which has occurred during previous atmospheric nuclear tests and nuclear reactor accidents.

* Correspondence and reprints

Tel.: 01690824 67; fax: 01690820 21; e-mail: bruns@ aquilon.cea.fr 
Owing to its chemical and biochemical similarities to calcium, more than $99 \%$ of strontium is efficiently incorporated into bone tissue and teeth. Characterized by a long physical and biological half-life ${ }^{1}$, ${ }^{90} \mathrm{Sr}$ may cause damage to bone marrow because of its high-energy $\beta$ particle $(\mathrm{E}=546 \mathrm{keV})$.

The Chernobyl nuclear reactor accident revealed the need for a rapid ${ }^{90} \mathrm{Sr}$ analytical method. The analytical time is considered as an important economic factor in connection with the closing down time of dairy farms suspected of having been in contact with clouds of radioactive dust.

In such an emergency situation, the determination of radiostrontium in a matrix such as milk is essential for several reasons; (a) milk ingestion is a substantial ${ }^{2}$ path of radiostrontium incorporation in the human body especially that of infants; (b) the milk is usually consumed as a fresh product, therefore industrial storage of milk is not practicable; (c) the strontium transfer from soil-plant to cow-milk is efficient; and (d) the milk contamination level gives an indication of the radiostrontium deposition over a wide area [17].

The EURATOM regulation published in the Official European Community Journal of July 22, 1989 [14] stipulates upper limits of radiostrontium activity in infant food and dairy products at 75 and $125 \mathrm{~Bq} \cdot \mathrm{kg}^{-1}$, respectively.

This regulation, which should be applied in emergency situations such as a nuclear accident, reveals that a low detection limit is not of first importance in comparison with analytical time.

A comparison of published methods is difficult for several reasons; some essential information is missing in the literature (yield or yield calculation, performance, procedure time, uncertainty and detection limit calculations); the aim of each method can be different (determination of: (a) total radiostrontium, and (b) ${ }^{90} \mathrm{Sr}$ and ${ }^{89} \mathrm{Sr}$, elimination of some interfering radionuclides such as ${ }^{140} \mathrm{Ba}$ ). In 1991, such a study was done by Wilken and Joshi [52]. The purpose of this paper is to examine the available methods for ${ }^{90} \mathrm{Sr}$ determination in milk, taking into account time and safety as priority factors.

\section{RADIONUCLIDES TRANSFER}

\subsection{Transfer of radiostrontium from soil to milk}

Cows ingest radionuclides with contaminated water and forage, and inhale them with the air. During fallout radionuclides are directly deposited on plants and partially absorbed into plant cells. During and for many years after the fallout, plants incorporate radionuclides through their roots. Comar and Wasserman [11] and Twardock et al. [48] have estimated that about $1 \%$ of the strontium present in forage is transferred into milk. Other studies estimated that $4-6 \%$ of strontium intake from a contaminated diet appear in cow milk [53]. Nevertheless, owing to its efficient root uptake and long lifetime, strontium can contaminate milk for decades after deposition.

The transfer of radionuclides in the food chain occurs in two major steps: the first from soil to plant, and the second shorter step from cow to milk. The plant/soil and milk/cow concentration ratios 3 are used for predicting radionuclide concentration in foodstuffs and dose impact to man. Their determination is rather difficult and the values are strongly influenced by many

\footnotetext{
${ }^{1}$ Physical half-life: 28.5 years / biological half-life: about 7 years.

2 In the literature, the relative contribution of milk to ${ }^{90} \mathrm{Sr}$ incorporation in the human organism varies.

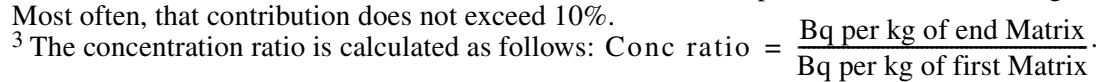


Table I. Approximate composition of milk [50].

\begin{tabular}{lccc}
\hline Component & $\begin{array}{c}\text { Average content percentage } \\
(\mathrm{w} / \mathrm{w})\end{array}$ & $\begin{array}{c}\text { Range percentage }(\mathrm{w} / \\
\mathrm{w})\end{array}$ & $\begin{array}{c}\text { Average percentage of } \\
\text { dry matter }\end{array}$ \\
\hline Water & 87.3 & $85.8-88.7$ & \\
Solids (not fat) & 8.8 & $7.9-10.0$ & 69 \\
Fat in dry matter & 31 & $21-38$ & 36 \\
Lactose & 4.6 & $3.8-5.3$ & 31 \\
Fat & 3.9 & $2.4-5.5$ & 26 \\
Protein & 3.25 & $2.3-4.4$ & 20 \\
Casein & 2.6 & $1.7-3.5$ & 5.1 \\
Mineral substances & 0.65 & $0.53-0.80$ & 1.4 \\
Organic acids & 0.18 & $0.13-0.22$ & 1.1 \\
Miscellaneous & 0.14 & &
\end{tabular}

physical, chemical and biological factors. For instance, investigations in Finland after the Chernobyl reactor accident have shown that the transfer of ${ }^{137} \mathrm{Cs}$ and ${ }^{90} \mathrm{Sr}$ from soil to plant differs according to the geographic site and plant species considered. In the southern area, the plant/soil concentration ratio of ${ }^{90} \mathrm{Sr}$ was about 9 times greater than that of the ${ }^{137} \mathrm{Cs}$ ratio [34].

The ${ }^{90} \mathrm{Sr}$ transfer from cow to milk is somewhat less efficient than the soil/plant transfer. After a single uptake by the cow, the maximum strontium concentration is reached after 1-2 d [34].

\subsection{Milk composition}

Milk is a complex fluid containing many components in several states of dispersion. A rough classification of the principal constituents of milk with approximate percentages of contents is given in Table I [50].

Milk and its derivatives are the main sources of calcium and phosphorus in general nutrition. The mineral composition of milk varies according to species (Tab. II) [9] and also to race; the calcium and phosphorus content in a "Normande" cow are larger than in a "Frisonne", "Pie Rouge" or "Holstein" cow. In theory, mineral concentration is not affected by nutrition. However, while this statement may be true for
Table II. Mineral composition of milk for several species $\left(\mathrm{g} \cdot \mathrm{L}^{-1}\right)[9]$.

\begin{tabular}{lcccc}
\hline & Cow & Goat & Sheep & Woman \\
\hline $\mathrm{Ca}$ & 1.20 & 1.30 & 1.90 & 0.31 \\
$\mathrm{P}$ & 0.90 & 0.95 & 1.50 & 0.15 \\
$\mathrm{Mg}$ & 0.12 & 0.12 & 0.16 & 0.037 \\
$\mathrm{~K}$ & 1.50 & 1.60 & 1.25 & 0.52 \\
$\mathrm{Na}$ & 0.45 & 0.40 & 0.45 & 0.15 \\
$\mathrm{Cl}$ & 1.15 & 1.40 & 0.70 & 0.50 \\
\hline
\end{tabular}

essential minerals that are under homeostatic control, it probably does not apply to non-essential elements such as strontium. Moreover, important variations are observed during the lactation period.

Speciation of ${ }^{90} \mathrm{Sr}$ in contaminated milk is of interest with respect to the bioavailability to the human organism, processing and decontamination of milk and radiochemical analysis.

The minerals in milk are mainly inorganic salts, partly ionized and partly present as complex salts. The mineral distribution between the soluble and colloidal phases of milk is heterogeneous. Temperature, $\mathrm{pH}$ and citrate content are the principal physical and chemical factors likely to change mineral distribution: saline concentration in the soluble phase increases when: (a) $\mathrm{pH}$ and temperature decrease, and (b) citrate 
Table III. Derivative:milk concentration ratio.

\begin{tabular}{lccc}
\hline & Fat rate & $\begin{array}{c}\text { Fermentation } \\
\text { type }\end{array}$ & ${ }^{85} \mathrm{Sr}_{\text {derivative }} /{ }^{85} \mathrm{Sr}_{\text {milk }}{ }^{1}$ \\
\hline Fresh cheese & fat & rennet & 3.91 \\
& & lactic ferment & 0.66 \\
& skim & rennet & 3.83 \\
Fermented cheese & & lactic ferment & 0.97 \\
Skim milk & & $4.7-6.6$ \\
Cream & \multirow{2}{*}{$24 \%$} & & 0.92 \\
Butter & & 0.6 \\
Casein & & rennet & 0.09 \\
& & acid & 20.5 \\
\hline
\end{tabular}

${ }^{1}$ Milk contamination by metabolic way.

concentration increases. Strontium is bound similarly to calcium, for example, to the phosphate groups of caseins, and consequently is located in about $80 \%$ of the milk's casein micelles $[27,29,50]$. At $\mathrm{pH}$ 6.6-6.8, less than $50 \%$ of the strontium content is exchangeable. By lowering the $\mathrm{pH}$ to 5.3, a major part of the strontium is transferred to the milk soluble phase [49].

\subsection{Transfer of radiostrontium from milk to its products}

The milk product:milk concentration ratios are given in Table III $[27,50]$. The higher ratio is obtained for casein when coagulation is carried out with rennet. Regarding cheese, the ratio between 3.8 and 6.6 is quite substantial, whereas the butter content is 11 times lower than the milk content.

\section{METHODS FOR DETERMINING RADIOSTRONTIUM IN MILK}

${ }^{89} \mathrm{Sr},{ }^{90} \mathrm{Sr}$ and its daughter ${ }^{90} \mathrm{Y}$ are practically pure $\beta$ emitters. Their disintegration schemes are given below.

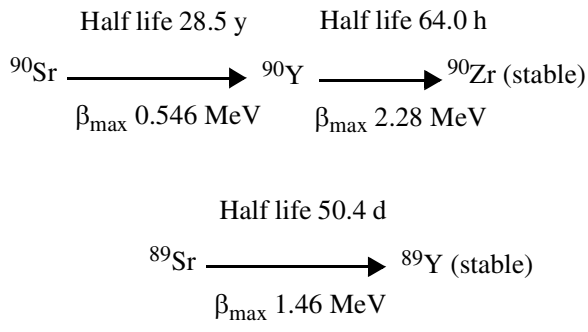

Figure 1 shows the time required to reach the secular equilibrium of the activities of ${ }^{90} \mathrm{Sr}$ and ${ }^{90} \mathrm{Y}$. The three radionuclides $\left({ }^{90} \mathrm{Sr},{ }^{89} \mathrm{Sr},{ }^{90} \mathrm{Y}\right)$ must be separated from a large amount of inactive matrix constituents (fats, proteins, minerals) and from a number of interfering radionuclides $\left({ }^{3} \mathrm{H},{ }^{14} \mathrm{C},{ }^{40} \mathrm{~K},{ }^{137} \mathrm{Cs}\right)$, prior to measurement. In addition, when the milk is contaminated with fresh fallout, ${ }^{140} \mathrm{Ba}$ and its daughter ${ }^{140} \mathrm{La}$ must be removed. The standard methods for determination of ${ }^{90} \mathrm{Sr}$ in milk are often laborious ${ }^{4}$ and time-consuming. The necessity of separating ${ }^{90} \mathrm{Sr}$ from ${ }^{90} \mathrm{Y}$ contributes to this. Three procedure examples are given in Figures 2, 3 and 4 . The first procedure (AOAC [3])

4 The determination of radiostrontium based on the nitrate strontium precipitation with fuming nitric acid requires nine different precipitation steps. 


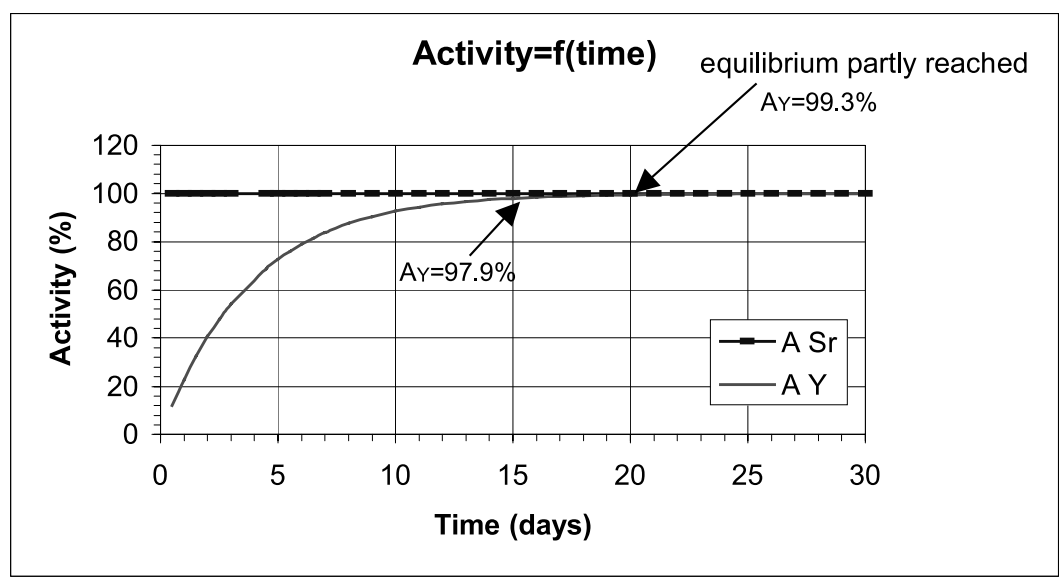

Figure 1. Secular equilibrium of ${ }^{90} \mathrm{Sr}$ and its daughter ${ }^{90} \mathrm{Y}$.

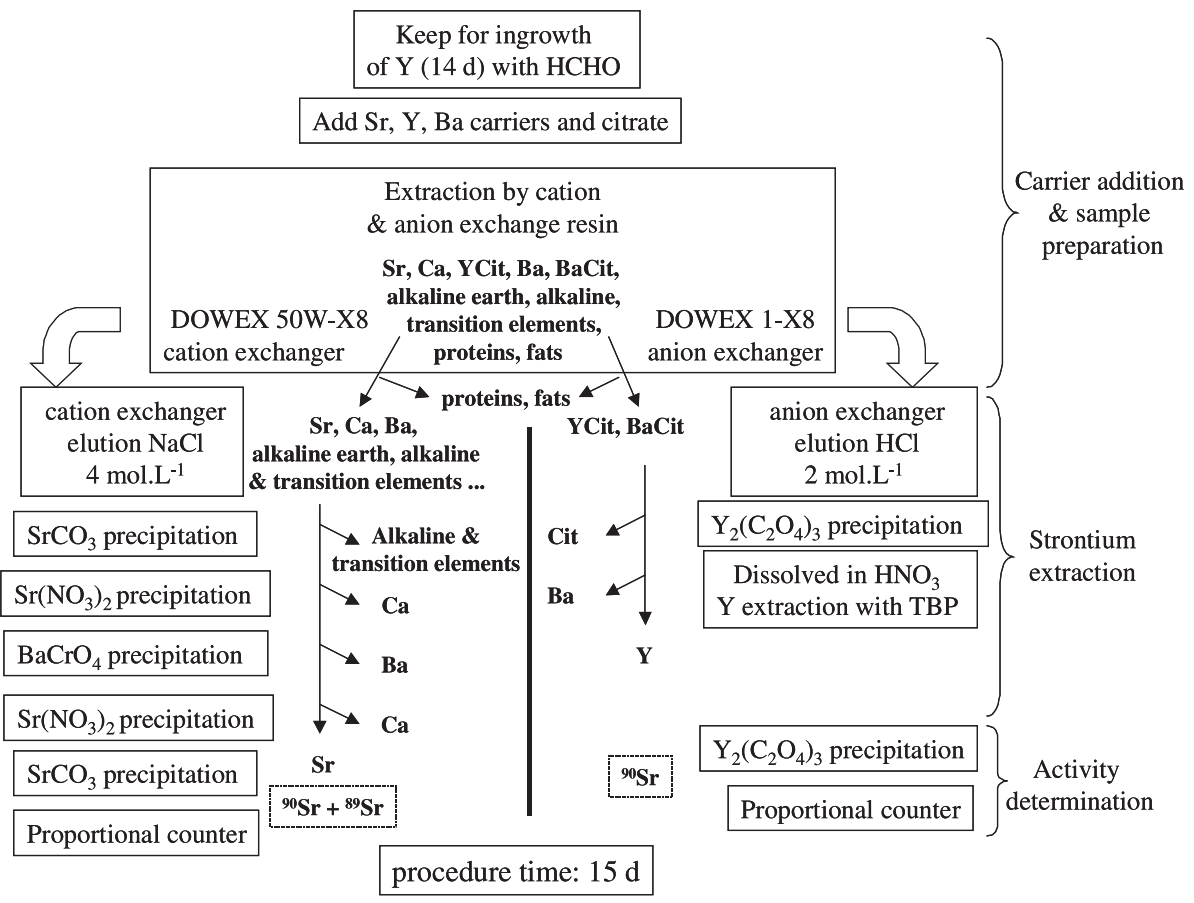

Figure 2. Determination of ${ }^{90} \mathrm{Sr}$ and ${ }^{89} \mathrm{Sr}$ in milk (from Baratta [3]).

determines ${ }^{89} \mathrm{Sr}$ and ${ }^{90} \mathrm{Sr}$ activities separately. The analysis requires at least $15 \mathrm{~d}$. Whereas, in an emergency situation, a sim- ple and rapid radiostrontium determination can be accomplished in $24 \mathrm{~h}$ as shown in Figure 3 (Vaney et al. [49]). Tait et al. [45] 


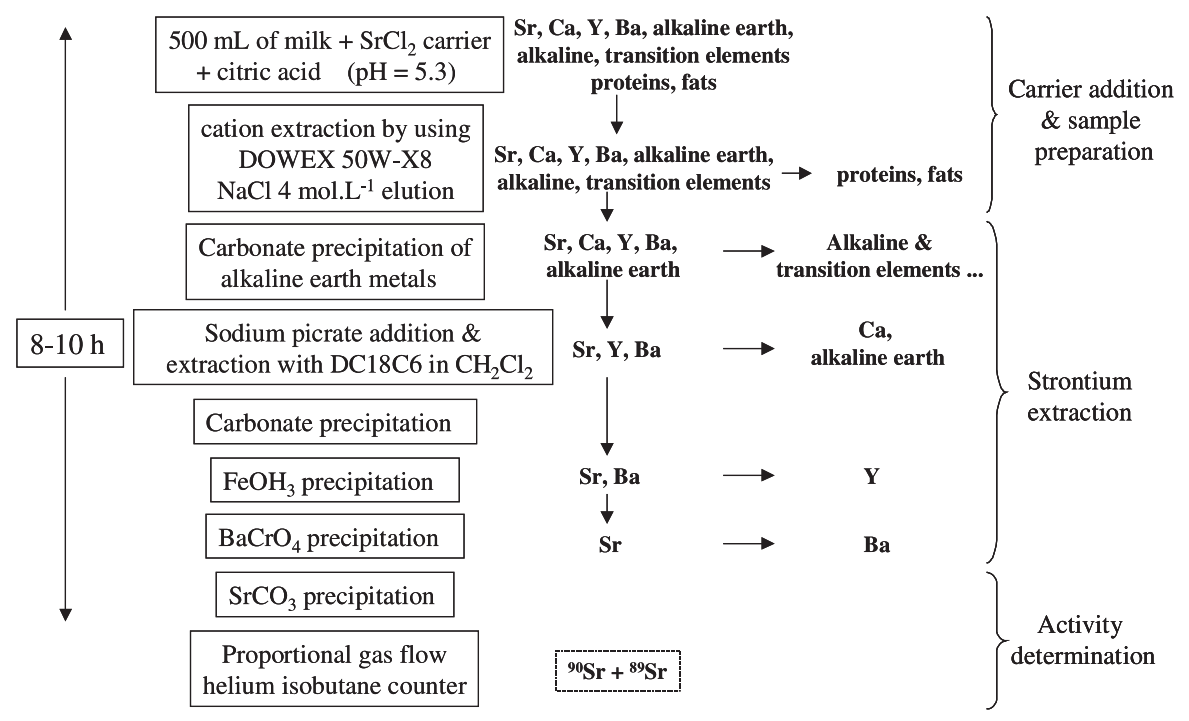

Procedure time: $24 \mathrm{~h}$

Figure 3. Rapid determination of radiostrontium 90 and 89 in milk (from Vaney et al. [49]).

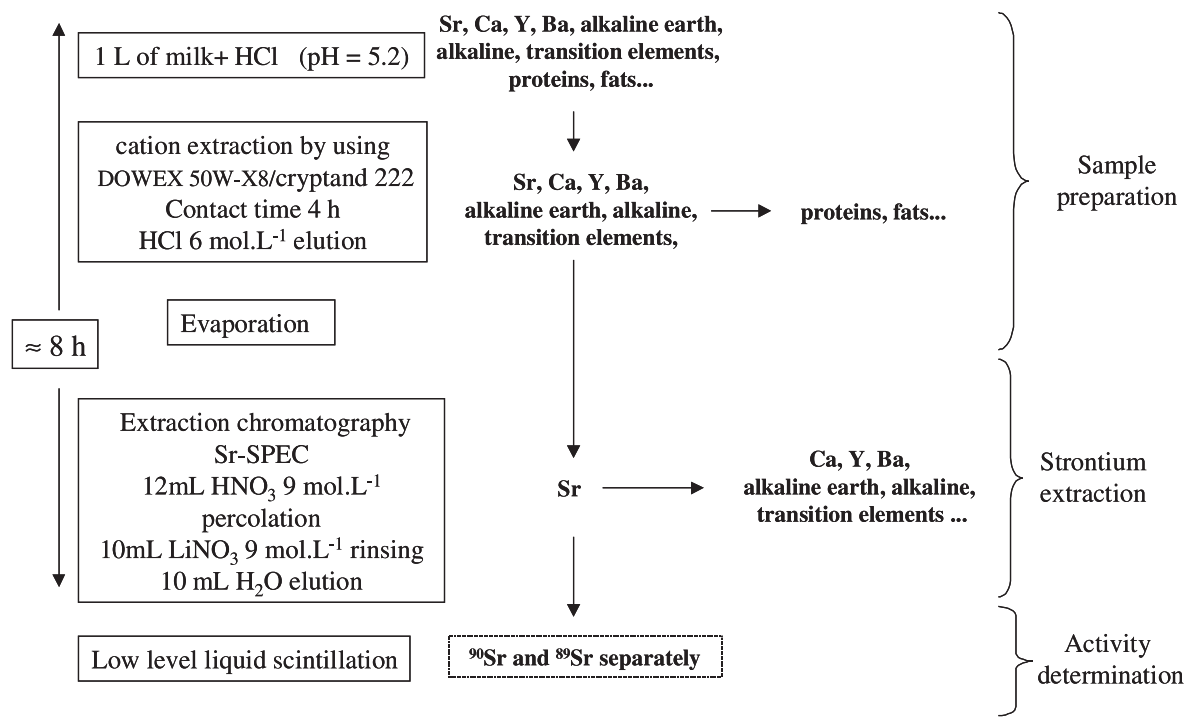

Procedure time: $24 \mathrm{~h}$

Figure 4. Rapid determination of ${ }^{90} \mathrm{Sr}$ and ${ }^{89} \mathrm{Sr}$ in milk (from Tait et al. [45]). 
quantified ${ }^{90} \mathrm{Sr}$ and ${ }^{89} \mathrm{Sr}$ separately in $24 \mathrm{~h}$ (Fig. 4).

The separation of strontium is based on four major steps: the carrier addition; the sample preparation; the radiostrontium extraction by chemical treatment, and the activity determination. The second, third and fourth steps are examined in succession, and discussed under the aspect of time saving.

\subsection{Carrier addition}

Two isotopes are commonly used as carriers to evaluate the chemical yield of ${ }^{90} \mathrm{Sr}$ separation. Strontium 85 , a $\gamma$ emitter characterized by a short half-life $(\mathrm{T}=$ $64.9 \mathrm{~d})$, is simply measured by gamma spectrometry $\left(\mathrm{E}_{\gamma}=514 \mathrm{keV}\right)$ [20]. The stable strontium 87 is also well adapted to a general analytical method. The chemical yield is measured by gravimetry or atomic absorption spectrometry (AAS). However, the gravimetric method is less precise.

The chemical yield of ${ }^{90} \mathrm{Y}$ is frequently determined by means of stable ${ }^{89} \mathrm{Y}$ as carrier. Numerous methods use yttrium oxalate precipitation for the gravimetric evaluation of chemical yield. Nevertheless, at room temperature, the amount of hydrated water considered for precipitate theoretical weight differs between 7 [38] and 9 [3,31].

Stable barium carrier is sometimes [3] used for $\mathrm{BaCrO}_{4}$ precipitation. Tait and Wiechen [42] used stable cesium carrier to reduce ${ }^{137} \mathrm{Cs}$ contamination.

\subsection{Sample preparation}

In most cases, the time required for the pretreatment operation depends on the amount of the sample. Pretreatment of smaller samples is faster, but a longer counting time is required.

Fresh milk samples are often preserved with formaldehyde (HCHO) or sodium azide $\left(\mathrm{NaN}_{3}\right)$ and stored to obtain ${ }^{90} \mathrm{Y}$ in the cases where ${ }^{90} \mathrm{Sr}$ and ${ }^{89} \mathrm{Sr}$ must be determined [3].
The classical procedure of milk sample pretreatment is carried out in three steps $[5,18,19,21,24,26,38]$; the sample is dried at about $105-110^{\circ} \mathrm{C}$ to a constant weight and incinerated in a muffle furnace between 400 and $600{ }^{\circ} \mathrm{C}$; then the ashes are most often dissolved in concentrated nitric acid (between 5 and $14 \mathrm{~mol} \cdot \mathrm{L}^{-1}$ ) except by Bouquiaux and Gillard-Baruh, who dissolved the ashes in concentrated hydrochloric acid $[6,7]$. Actually, this pretreatment is different for each method with respect to, the temperature chosen and sometimes the temperature gradient used, and the nitric acid concentration and temperature used for dissolution. Moreover, the evaporation time is strongly dependent on sample volume.

Although calcination pretreatment is efficient and commonly used, there is no doubt that it is time-consuming $(>1 \mathrm{~d})$ $[4,16,25,26,31]$.

In a recent paper, Abbadi et al. [1] incinerated the milk sample directly without any time-consuming drying stages in an electrically-heated fluidized bed reactor made of quartz at $650{ }^{\circ} \mathrm{C}$ using compressed air. The milk is conveyed with a flow rate of $5 \mathrm{~mL} \cdot \mathrm{min}^{-1}$ so that less than $2 \mathrm{~h}$ are required to ash $0.5 \mathrm{~L}$ of milk.

An alternative "leaching procedure" [19] requires boiling and evaporating milk samples with $50 \mathrm{~mL}$ of $65 \%$ nitric acid (3 times) to dryness, taking up in $2 \mathrm{~mol} \cdot \mathrm{L}^{-1}$ nitric acid and warming for $30 \mathrm{~min}$ for dissolution, then cooling and centrifuging. The supernatant is collected for the separation step. Except for the evaporation step, which still requires a subsequent amount of time, the time saving is accomplished by replacing the calcination step with the short leaching acid procedure (about $1 \mathrm{~h}$ ).

Mikulaj and Svec [31] proposed, when ${ }^{90} \mathrm{Sr} /{ }^{90} \mathrm{Y}$ radioactive equilibrium is reached, adding concentrated nitric acid, to precipitate proteins and the major part of the fats. The precipitate and supernatant are separated by centrifugation and filtration after being heated at $90{ }^{\circ} \mathrm{C}$ and left at room 
temperature for $2 \mathrm{~h}$. The disadvantage of such a procedure is that a substantial part of the fats remains in the analytical solution.

The strontium extraction from milk is frequently carried out with exchange or chelating resins which have a strong affinity for alkaline earth cations. Initial investigations were carried out in order to reduce milk contamination. In 1954, Nervik et al. reported by Kirchman [27] studied milk decontamination from strontium by means of cation exchange resins. In 1960, Migikowsky [30] also developed a milk decontamination process which required the cation exchange resin Dowex 50-X12 (sulfonate groups) for strontium extraction. Successively, mass of resin: volume of milk ratio, number of treatments, contact time, temperature and resin form $(\mathrm{Ca}, \mathrm{Na}, \mathrm{K}, \mathrm{CaNaK})$ are treated. The best extraction yield reached was $97 \%$. These extraction techniques were applied in sample preparation of radiostrontium analysis in order to save time.

Ovarec and Navarcik [33] chose to preconcentrate radiostrontium on a strong acid cation exchanger OSTION KS-0807 (amine groups) under static conditions. The authors estimate that the procedure is 8 times faster than the drying and calcination method.

To determine ${ }^{89} \mathrm{Sr}$ and ${ }^{90} \mathrm{Sr}$, the Association of Analytical Chemists (AOAC) [3] suggests the use of a double column which contains at the top anion exchange resin (Dowex 1-X8 trimethyl ammonium group, for yttrium/citrate complex extraction) and at the bottom cation exchange resin (Dowex 50W-X8, sulphonate group, for $\mathrm{Sr}, \mathrm{Ca}$ and $\mathrm{Ba}$ extraction).

Tait and Wiechen [42] treated the milk in a batch procedure with a Chelite $\mathrm{P}$ resin ${ }^{5}$ (aminomethylphosphonate group) in $\mathrm{Na}^{+}$ form. The contact time is between 30 and $40 \mathrm{~min}$ at $65-70{ }^{\circ} \mathrm{C}$ in a water bath. The strontium is eluted with diluted nitric acid.
To reduce the milk/resin contact time, Vaney et al. [49] adjusted the $\mathrm{pH}$ of milk to 5.3 with citric acid and mixed it with Dowex 50W-X8 resin for $15 \mathrm{~min}$, then after decantation, the supernatant was first transferred to a chromatographic column containing $5 \mathrm{~mL}$ of fresh resin, followed by the resin itself. The procedure can be achieved in less than $1 \mathrm{~h}$ and the yttrium separation yield reaches $74 \%$.

In 1995, Tait et al. [43] bound a bicyclic polyether cryptand C222 to several resins to improve their affinity for strontium. For the Dowex 50W-X8 system termed "D/ 222", the sorption of strontium from milk is about $30 \%$ greater than sorption by the corresponding untreated resin. The column is washed with $10 \mathrm{mg} \cdot \mathrm{mL}^{-1}$ solution of stable cesium to remove milk traces and minimize contamination of radiostrontium sorbed with radiocesium. Two years later $[44,45]$, the same authors extracted more than $95 \%$ of strontium with $\mathrm{D} / 222$ under the following conditions: the volume ratio of resin to milk is 1:50; the $\mathrm{pH}$ of the milk is adjusted to between 4.8-5.4; the contact time is about $4 \mathrm{~h}$ at $22^{\circ} \mathrm{C}$.

There is no doubt that the ion exchange method is faster than the calcination method (except for the use of a fluidized bed reactor). However, in cases where the milk contains more cream or curd, Jeter and Grob suggest the second method [25].

For goat milk Comar and Wasserman [11] and Twardock et al. [48] observed a substantial difference between spiked strontium (66\% for extraction yield) and metabolic strontium (86\% for extraction yield) by using the ion exchange method. That difference may be explained by a greater concentration of calcium in goat milk than in bovine milk. Ion exchangers with a relatively small amount of Sr-specific binding sites probably become saturated with either strontium or interfering ions such as calcium. Thomas [47] demonstrated that strontium metabolized and

$5100 \mathrm{~mL}$ of milk for $15 \mathrm{~g}$ of resin. 
secreted into milk by the cow could be removed in the same manner as strontium directly spiked in milk.

It is obvious that the sample preparation time can be significantly reduced by ion exchange techniques under precise conditions.

\subsection{Strontium extraction}

Since the sixties, a large variety of procedures have been described in order to separate and purify radiostrontium and radioyttrium. The different procedures are selective precipitation, liquid-liquid extraction and solid-liquid extraction. All the techniques available are successively examined and discussed, as far as possible.

\subsubsection{Precipitation}

This technique is based upon different solubilities of cations in a given solution. For this purpose fuming nitric acid is often used $[15,20,24]$ to separate strontium from calcium, although these conditions are difficult and dangerous for health (concentration acid >90\%). The strontium/ calcium separation is also feasible by using different solubilities of strontium and calcium oxalates (in presence of a large excess of calcium [10]).

Other interfering cations such as ${ }^{140} \mathrm{Ba}$ or ${ }^{90} \mathrm{Y}$ require specific precipitation steps to be extracted. In most procedures which consider a fresh nuclear reactor accident, the probable presence of ${ }^{140} \mathrm{Ba}$ and its daughter ${ }^{140} \mathrm{La}$ in milk requires their extraction by means of chromate precipitation [3, 20, 24-26, 29, 33, 49]. The chromate precipitation is also well suited to the selective extraction of ${ }^{210} \mathrm{~Pb}$. The strontium/yttrium separation is carried out by coprecipitation with iron hydroxide $[4,24$, 26,49 ], or selective precipitation of yttrium hydroxide [25, 33, 39].

Other precipitation reactions (phosphate, carbonate, oxalate, sulfate) are often used to eliminate, among other things, traces of ${ }^{137} \mathrm{Cs}$ and ${ }^{40} \mathrm{~K}$.
Though precipitation steps are frequently used, they are tedious [16] and must often be repeated several times [29] to obtain adequate purity of strontium. They consequently lead to large losses of strontium.

\subsubsection{Liquid - liquid extraction}

In the case where ${ }^{90} \mathrm{Y}$ is in secular equilibrium with ${ }^{90} \mathrm{Sr}$, numerous methods use TBP (tributyl phosphate) [3, 4, 31, 38] or HDEHP (Bis(2-ethylhexyl) phosphoric acid) [16] extraction of ${ }^{90} \mathrm{Y}$ from aqueous acid. The technique enables us to determine activity due to ${ }^{90} \mathrm{Sr}$ and ${ }^{89} \mathrm{Sr}$ separately by quantifying simultaneously ${ }^{90} \mathrm{Y}$ and total radiostrontium activity. However, these efficient methods require more than $15 \mathrm{~d}$ to reach secular equilibrium.

Kimura et al. [26], among others [49], have proposed the extraction of strontium from a large amount of calcium by liquidliquid extraction with a macrocyclic ether (dicyclohexyl-18-crown-6, DC18C6) into chloroform. These methods give a sufficient decontamination factor, except for ${ }^{140} \mathrm{Ba}$ which follows strontium in the chemical operation. Consequently, chromate precipitation has to be carried out to remove barium.

Tait and Wiechen [42] have used the crown ether DC18C6 into chloroform followed by extraction of barium into dichloromethane containing 21 crown 7 (21C7). The limitation of the procedure is the generation of organic solvent wastes. The disposal of such wastes is difficult and expensive.

\subsubsection{Chromatographic methods}

\subsubsection{Ion exchange chromatography}

Stella et al. [39, 40] have used two cation exchangers; tin dioxide and copper chromate, which have simultaneously a strong affinity, respectively, for alkaline earth and barium, and no affinity for alkali 
metal ions such as cesium, sodium and potassium. The use of both exchangers allows direct extraction of $75 \%$ of strontium from milk previously skimmed by centrifugation.

Grahek et al. [21] carried out the strontium/calcium separation from milk ash by means of the anion exchanger amberlite CG-400 (Quaternary ammonium group) and $0.25 \mathrm{~mol} \cdot \mathrm{L}^{-1} \mathrm{HNO}_{3}$ in methanol as eluent for calcium. However, the method required 3 precipitation steps to remove yttrium and barium.

In 1967, Noshkin and Mott [32] used complexing agent to separate strontium and calcium. After sorption on ion exchange columns (Dowex 50-X12), strontium and calcium can be eluted separately by complex formation with cyclo-hexanediaminetetra-acetic acid (CyDTA) and careful control of $\mathrm{pH}$. In the same way, Bouquiaux and Gillard-Baruh [6, 7] substituted ethylenediaminetetra-acetic acid (EDTA) for CyDTA.

Abbadi et al. [1] used successively 2 different ion chromatography columns for selective extraction of strontium. Firstly, coarse-grained AMP (molybdophosphoric acid) filled in a column allowed them to separate strontium from alkaline ions. Secondly, an acidic cation exchanger was used to separate strontium from transition metal ions $\left(\mathrm{Fe}^{3+}, \mathrm{Cu}^{2+}, \mathrm{Zn}^{2+}, \mathrm{Ru}^{3+}, \mathrm{Co}^{3+}\right)$, alkaline earth ions $\left(\mathrm{Ca}^{2+}, \mathrm{Ba}^{2+}\right)$ and other elements such as lead $\left(\mathrm{Pb}^{2+}\right)$ by means of an EDTA pH gradient. Both columns are integrated into a HPLC system.

Heilgeist [22] used ion chromatography as an ideal technique for a radiochemical fine purification. It was mainly intended to separate $\mathrm{Sr}$ from $\mathrm{Ba}$ when the separation by extraction chromatography was not complete.

\subsubsection{Extraction chromatography}

Horwitz et al. [23] have developed a novel extraction chromatographic resin for strontium, "Sr-SPEC", consisting of an octanol solution of $4,4^{\prime}\left(5^{\prime}\right)$-bis(t-butyl- cyclohexano)-18-crown-6 sorbed on an inert polymeric support. The resin has shown excellent selectivity for strontium over a number of alkali, alkaline earth and other metal cations. Most often, percolation, rinsing and elution can be carried out in about $3 \mathrm{~h}$.

Because of its simplicity, rapidity and efficiency, numerous teams [2, 18-20, 25, 42-45] have used the "Sr-SPEC" resin for strontium analysis in milk. However, the resin cannot be used directly with liquid milk but only with a fairly "clean" extract. Furthermore, the resin inefficiently separates strontium from barium. However, Tait et al. $[44,45]$ proposed an elution procedure which enables us to separate both elements. The second limitation of such a material is a low regeneration power ( $\geq 4$ times) which incurs a substantial cost for routine analysis. They have obtained about $10 \%$ decrease in chemical yield for third and fourth usages [45].

Recently, Tait et al. [46] succeeded in separating strontium from calcium on the $\mathrm{D} / 222$ system in order to eliminate the "Sr SPEC" separation step. Previously to acid elution of strontium, calcium is removed by adding $300 \mathrm{~mL}$ of an aqueous solution containing $0.1 \mathrm{~mol} \cdot \mathrm{L}^{-1}$ pentasodium tripolyphophate $\mathrm{Na}_{5} \mathrm{P}_{3} \mathrm{O}_{10}$ and stir ring for $40 \mathrm{~min}$. Then, ${ }^{140} \mathrm{Ba}$ and its daughter ${ }^{140} \mathrm{La}$ can be separated from $\mathrm{Sr}$ by adjusting the acid eluate from the $\mathrm{D} / 222$ to a $\mathrm{pH}$ value of 3 and passing it through a column containing $0.5 \mathrm{~g}$ of manganese dioxide. However, that $\mathrm{Sr} / \mathrm{Ba}$ separation requires further optimization.

From the above considerations regarding chemical separation procedures, it is obvious that no significant time saving can be obtained in the strontium separation step.

\subsection{Activity determination}

The activity determination by all available techniques is most often well separated from radiochemical separation. However, Abbadi et al. [1] detected ${ }^{90} \mathrm{Sr}$ and ${ }^{89} \mathrm{Sr}$ 
online with the help of an installed HPLC detector. Lamb et al. [28] have automated an entire separation system under computer control.

The pure $\beta$ emissions from ${ }^{90} \mathrm{Sr},{ }^{89} \mathrm{Sr}$ and ${ }^{90} \mathrm{Y}$ can be measured with a proportional counter, a liquid scintillation counter and a surface barrier detector. In the case of ${ }^{89} \mathrm{Sr}$ and especially ${ }^{90} \mathrm{Y}$, the high particle energies enable us to use a fourth detection system: the Cerenkov counter. The determination of ${ }^{90} \mathrm{Sr}$ and ${ }^{89} \mathrm{Sr}$ can also be carried out with a non-radiometric technique based on mass spectrometry. The limit of detection is not systematically given to compare counting techniques because the given values are not determined in the same conditions (sample volume, chemical recovery, counting time...).

\subsubsection{Proportional counter}

Largely used [3, 20, 21, 26, 31, 33, 39, $40,49]$ for its convenience, low background $(0.5 \mathrm{dpm})$, significant efficiency (about 50\%) and relative immunity from $\alpha$ interferences, the proportional counter is the oldest technique. Nevertheless, this counting system is unable to discriminate the $\beta$ particles of each of the elements ${ }^{90} \mathrm{Sr}$, ${ }^{89} \mathrm{Sr}$ and ${ }^{90} \mathrm{Y}$. Consequently, in the case of ${ }^{90} \mathrm{Y}$ elimination prior to radiostrontium counting, the content of ${ }^{90} \mathrm{Sr}$ and ${ }^{89} \mathrm{Sr}$ must be evaluated by the degree of ${ }^{90} \mathrm{Y}$ ingrowth at some interval of time after the $\mathrm{Sr} / \mathrm{Y}$ separation. Broadway and Guy [8] show how a generalized linear system of equations may be used to solve this problem when considering measurements taken after additional time intervals. The mathematical model can be carried out by using a simple linear regression. Sutherland [41] compares count data against a spreadsheetcalculated matrix of ingrowth/decay curves from 0 to $100 \%{ }^{90} \mathrm{Sr}$ and at the analytical count intervals between about 24 to $650 \mathrm{~h}$ after the $\mathrm{Sr} / \mathrm{Y}$ separation, to determine the best fit of the data set. Therefore, the fit allows him to calculate ${ }^{90} \mathrm{Sr}$ and ${ }^{89} \mathrm{Sr}$ percentages in the sample.
Both methods gave satisfactory results and can be carried out with a simple Excel spreadsheet. However, they require about 10 measurements, so that $10 \mathrm{~d}$ are needed to obtain acceptable standard of deviations (about 3\%), leading to a total analytical time of over $11 \mathrm{~d}$.

Most often, the limit of detection is about $5-100 \mathrm{mBq} \cdot \mathrm{L}^{-1}$ for a sample volume of $1 \mathrm{~L}$, with a counting time of between $1-2 \mathrm{~h}$ and a chemical recovery of over $50 \%$.

\subsubsection{Liquid scintillation detector}

Although the lower background obtained with ultra low level liquid scintillation $(>3 \mathrm{dpm})$ is greater than for the proportional counter, liquid scintillation is frequently used $[2,5,18,19,23,28,36,42-45]$ because it gives a $\beta$ spectral distribution for the three radionuclides. Furthermore, liquid scintillation is characterized by a high counting efficiency $\left(>85 \%\right.$ for ${ }^{90} \mathrm{Sr}$ and ${ }^{90} \mathrm{Y}$ ) and avoids counting problems such as self absorption, poor geometry or nonuniformity of sample mounting.

Among methods which attempted to assay for ${ }^{90} \mathrm{Sr}$ in non-equilibrium, Piltingsrud and Stencel [36] used Cab-O-Sil gelling agent to suspend an insoluble strontium precipitate of a sample containing ${ }^{90} \mathrm{Y}$, ${ }^{90} \mathrm{Sr}$ and ${ }^{89} \mathrm{Sr}$, and a spectrum-unfolding computer program to determine the quantity of each of the three isotopes.

As reported by Passo and Cook [35], Heilgeist [22] uses a calculation program that defines three energy windows on the liquid scintillation analyzer. The calibration of the spectrometer and the evaluation of the sample spectrum require spectra of the background and of the reference preparations, which contain only one of the radionuclides ${ }^{89} \mathrm{Sr},{ }^{90} \mathrm{Sr}$ and ${ }^{90} \mathrm{Y}$. After elimination of the background, ${ }^{90} \mathrm{Y}$ is calculated on the basis of its undisturbed share in window [816-950 keV], ${ }^{89} \mathrm{Sr}$ is determined after deduction of ${ }^{90} \mathrm{Y}$ in window [690$815 \mathrm{keV}]$, and finally, after deduction of ${ }^{89} \mathrm{Sr}$ and ${ }^{90} \mathrm{Y},{ }^{90} \mathrm{Sr}$ is calculated in channels 
$[<690 \mathrm{keV}]$, according to the spectra subtraction method. However, in the case where the concentration ratio of ${ }^{90} \mathrm{Sr} /{ }^{89} \mathrm{Sr}$ is over or under the unit, the deviation of the minor component increases as well.

The limit of detection is about 10 $100 \mathrm{mBq} \cdot \mathrm{L}^{-1}$ for a sample volume between $1-4 \mathrm{~L}$, with a counting time of between $1-2 \mathrm{~h}$ and a chemical recovery of over $80 \%$ $[13,35]$.

\subsubsection{The Cerenkov detector}

Cerenkov counting was first employed by Randolph [37]. Owing to the high Cerenkov counting efficiency for ${ }^{89} \mathrm{Sr}$ and ${ }^{90} \mathrm{Y}$ $(>40 \%)$ and the low efficiency for ${ }^{90} \mathrm{Sr}$ $(<1.4 \%)$, the activity determined from a sample containing a fresh mixture of ${ }^{90} \mathrm{Sr}$ and ${ }^{89} \mathrm{Sr}$ is entirely due to ${ }^{89} \mathrm{Sr}$ [12].

The lowest background acquired in low level count mode using glass scintillation vials is about $6 \mathrm{dpm}$.

Wilken and Joshi [52] mention that the use of a ${ }^{85} \mathrm{Sr} \gamma$ emitter as a yield monitor should be avoided if Cerenkov counting is to be performed at very low levels, and a non-radiometric technique is proposed.

Passo and Cook [35] reported that Rucker obtained a limit of detection of $0.35 \mathrm{~Bq} \cdot \mathrm{L}^{-1}$ for ${ }^{89} \mathrm{Sr}$ and $0.29 \mathrm{~Bq} \cdot \mathrm{L}^{-1}$ for ${ }^{90} \mathrm{Sr}$, for $1 \mathrm{~L}$ samples, with a $20 \mathrm{~min}$ count time and $80 \%$ chemical recovery.

\subsubsection{Surface barrier detector}

Wilken and Joshi [52] report that Mink used a silicon surface barrier detector system to obtain $\beta$ particle spectra. The system is able to resolve the different peaks arising in the conversion electron spectra for radionuclides such as ${ }^{207} \mathrm{Bi}$. In the case of $\beta$ particle emissions from radionuclides such as ${ }^{90} \mathrm{Sr},{ }^{89} \mathrm{Sr}$ and ${ }^{90} \mathrm{Y}$, the particle energy varies continuously from zero to maximum energy. Consequently, the surface barrier detector is unable to discriminate these $\beta$ particle emissions.

The background is of a few counts a day, so the limit of detection can be signi- ficantly lower than that of the proportional counter. The major advantage of this system is to be able to solve the lead's problem. In fact, the possible presence of ${ }^{210} \mathrm{~Pb}(\beta$ emitter) in a sample will cause an interference because of its chemical similarities with strontium. By using the surface barrier detector the ${ }^{210} \mathrm{Bi}$ daughter of ${ }^{210} \mathrm{~Pb}$ can be detected .

\subsubsection{Mass spectrometry}

Wendt et al. [51] used a non-radiometric technique for ultra traces analysis of ${ }^{90} \mathrm{Sr}$ and ${ }^{89} \mathrm{Sr}$ by combining conventional mass spectrometry with collinear laser resonance ionization spectroscopy. The limit of detection for ${ }^{90} \mathrm{Sr}$ is like that of the radiometric techniques previously described $(2 \mathrm{mBq})$; for ${ }^{89} \mathrm{Sr}$ the limit of detection is still too high $(15 \mathrm{~Bq})$. The technique requires a separation of strontium from calcium and barium, which would interfere during the subsequent atomization and ionization process.

In the case where the sample contains large quantities of stable strontium, the selectivity reached is not high enough to enable ultra traces determination of ${ }^{90} \mathrm{Sr}$ and ${ }^{89} \mathrm{Sr}$.

\section{DISCUSSION}

Following a nuclear reactor accident, milk produced in a contaminated area usually undergoes regular checking for radiostrontium. A rapid analytical method (performed in less than $2 \mathrm{~d}$ ) is required for the application of the EURATOM regulation [14], in order to screen a large number of milk samples in a short period of time and to minimize the contamination of all the dairy food chain. In the presence of interferents such as ${ }^{140} \mathrm{Ba},{ }^{134} \mathrm{Cs},{ }^{137} \mathrm{Cs} . .$. , existing detectors are unable to adequately resolve the spectra of the three radionuclides ${ }^{90} \mathrm{Sr},{ }^{89} \mathrm{Sr}$ and ${ }^{90} \mathrm{Y}$. In addition to counting technology delay, an important radiochemical separation is required. Two different approaches are possible for radiostrontium determination. The first is a 
radiochemical procedure based on ${ }^{90} \mathrm{Y}$ analysis with the intent of determining ${ }^{90} \mathrm{Sr}$ and ${ }^{89} \mathrm{Sr}$ separately. It is the best method for a specific determination of ${ }^{90} \mathrm{Sr}$. However, it needs more than $15 \mathrm{~d}$ to reach secular equilibrium, and so is inappropriate for managing an emergency situation.

The second consists of measuring radiostrontium activity after several radiochemical separations. Many rapid methods are available according to the nature of the interferences and the level of the selectivity required. Among them, though the nitrate precipitation with fuming nitric acid followed by several other steps is considered to be one of the most selective methods, it is tedious and time-consuming. Moreover, the fuming nitric acid manipulation is dangerous. On the other hand, Tait et al. [45] have developed a simple and efficient procedure for a crisis situation. The sample preparation is strongly accelerated by using cation exchange resin, then the strontium separation is carried out by using crown ether extraction chromatography. ${ }^{89} \mathrm{Sr}$ and ${ }^{90} \mathrm{Sr}$ are determined with a liquid scintillation analyzer and a simple calculation program.

Among all the available detection systems, liquid scintillation is particularly well adapted for the quantification of ${ }^{90} \mathrm{Sr},{ }^{89} \mathrm{Sr}$ and ${ }^{90} \mathrm{Y}$. Its high background (about $3 \mathrm{dpm}$ ) is well under the minimum value required for the application of the EURATOM regulation. Furthermore, the ability of the system to screen the 3 radionuclides allows one to save a significant amount of time.

In the case where the proportional counter is used, the ${ }^{89} \mathrm{Sr}$ and ${ }^{90} \mathrm{Sr}$ activities can be discriminated by following the activity decay. The mathematical treatment is effective under one major condition: the $\mathrm{A}_{89_{\mathrm{Sr}}}: \mathrm{A}_{90_{\mathrm{Sr}}}$ ratio must have a certain minimal value so that deviation in the observed activity induced by ${ }^{89} \mathrm{Sr}$ decay is greater than the counting uncertainty. The time required to determine activity due to ${ }^{89} \mathrm{Sr}$ and to ${ }^{90} \mathrm{Sr}$ shortens with the increasing value of the $A_{89_{S r}}: A_{90_{S r}}$ ratio.
Detection systems based on mass spectrometry have the great advantage of significantly reducing chemical operations compared with traditional radioactivity counting. However, these techniques still require the separation of ${ }^{89} \mathrm{Sr}$ and ${ }^{90} \mathrm{Sr}$ from a large amount of stable strontium. Furthermore, the limit of detection given for ${ }^{89} \mathrm{Sr}$ is still too high.

\section{CONCLUSION}

The comparison of different methods is quite difficult because the objectives are not always the same. In an emergency situation related to a nuclear reactor accident, a rapid estimation of the radio-strontium present in milk will prevail. In this way, available rapid methods are able to give a result in less than two days. A significant amount of time can be saved in the sample preparation steps by using ion exchange chromatography. Furthermore, simple mathematical treatments of the liquid scintillation spectrum allow a rapid ${ }^{89} \mathrm{Sr}$ and ${ }^{90} \mathrm{Sr}$ discrimination.

Finally, detection systems based on mass spectrometry allow new prospects relating to ${ }^{90} \mathrm{Sr}$ determination. The radiochemical separation can be strongly minimized.

\section{REFERENCES}

[1] Abbadi S., Diercks H., Knöchel A., Sen Gupta R., Tödter K., Rapid procedures for the determination of radioactive strontium isotopes in food and environmental samples, Kerntechnik 62 (1997) 91-95.

[2] Alvarez A., Navarro N., Salvador S., New method for ${ }^{90} \mathrm{Sr}$ determination in liquid samples, J. Radioanal. Nucl. Chem. 191 (1995) 315-322.

[3] Baratta E.J., Strontium-89 and strontium-90 in milk, in: Horwitz W. (Ed.), Official Methods of Analysis of AOAC International, 17th edn. AOAC International, Gaithersburg, Maryland, USA, chapter 13, 2000, pp. 3-6.

[4] Bem H., Bakir Y.Y., Shukerb S.M., A rapid method for the determination of ${ }^{90} \mathrm{Sr}$ in powdered milk, J. Radioanal. Nucl. Chem. 147 (1991) 263-268. 
[5] Benzi P., Operti L., Volpe P., On the reliability of a rapid method for the determination of strontium-90 in natural samples, J. Radioanal. Nucl. Chem. 126 (1988) 245-256.

[6] Bouquiaux J., Gillard-Baruh J.C.H., Détermination du strontium radioactif après séparation par l'EDTA sur résine cationique, Radiochim. Acta 9 (1968) 153-157.

[7] Bouquiaux J., Gillard-Baruh J.C.H., Séparation du strontium sur résine cationique pour la détermination du strontium radioactif, Radiochim. Acta 14 (1970) 39-43.

[8] Broadway J.A., Guy G.Y., Calculation of ${ }^{90} \mathrm{Sr}$ and ${ }^{89} \mathrm{Sr}$ concentrations in environmental samples using a generalized linear system, Health Phys. 47 (1984) 458-462.

[9] Brulé G., Les minéraux, in: CEPIL-INRA, (Éd.), Le lait matière première de l'industrie laitière, CEPIL, Paris/INRA, Versailles, France, 1987, pp. 87-98.

[10] Bunzl K., Kracke W., A simple radiochemical determination of ${ }^{90} \mathrm{Sr}$ in environmental samples, J. Radioanal. Nucl. Chem. 148 (1991) 115-119.

[11] Comar C.L., Wasserman R.H., Strontium, in: Comar C.L., Bronner F. (Eds.), Mineral metabolism an advance treatise 2, part A, Academic Press, New York, USA, 1964, pp. 523-566.

[12] Cook G.T., Passo Jr C.J., Carter B., Strontium-89 and-99, in: L'Annunziata M.F. (Ed.), Handbook of radioactivity analysis, Academic Press, San Diego, USA, 1998, pp. 369-370.

[13] De Regge P., Radecki Z., Moreno J., Burns K., Kis-Benedek G., Bojanowski R., The IAEA proficiency test on evaluation of methods for ${ }^{90} \mathrm{Sr}$ measurement in a mineral matrix, J. Radioanal. Nucl. Chem. 246 (2000) 511-519.

[14] EURATOM, Niveaux maximaux admissibles pour les denrées alimentaires et les aliments pour bétail après un accident nucléaire ou dans toute autre situation d'urgence radiologique, J. Off. Commun. Eur., règlement $\mathrm{N}^{\circ} 2218 / 89$ du 22/07/89.

[15] Florou H., Savidou A., Chaloulou C., Strontium-90 activity in monthly milk samples from Greece, J. Dairy Sci. 79 (1996) 1679-1682.

[16] Fourie H.O., Ghijsels J.P., Radiostrontium in biological material: a precipitation step and extraction procedure eliminating the use of fuming nitric acid, Health Phys. 17 (1969) 685-689.

[17] Galle P., Toxiques nucléaires, 2nd edn. Masson, Paris, France, 1998.
[18] Gastberger M., Steinhäusler F., Gerzabek M.H., Hubmer A., Lettner H., ${ }^{90} \mathrm{Sr}$ and ${ }^{137} \mathrm{Cs}$ in environmental samples from Dolon near the Semipalatinsk nuclear test site, Health Phys. 79 (2000) 257-265.

[19] Gjeçi E., Analysis in environmental and biological samples by extraction chromatography using a crown ether, J. Radioanal. Nucl. Chem. 213 (1996) 165-174.

[20] Goutelard F., Nazard R., Bocquet C., Coquenlorge N., Letessier P., Calmet D., Improvement in ${ }^{90} \mathrm{Sr}$ measurements at very low levels in environmental samples, Appl. Radiat. Isotopes 53 (2000) 145-151.

[21] Grahek Z., Lulic S., Kosutic K., Eskinja I., Cerjan S., Kvastek K., Separation of radioactive strontium from natural samples by means of mixed-solvent anion exchange, J. Radioanal. Nucl. Chem. 189 (1995) 141-146.

[22] Heilgeist M., Use of extraction chromatography, ion chromatography and liquid scintillation spectrometry for rapid determination of strontium-89 and strontium-90 in food in cases of increased release of radionuclides, J. Radioanal. Nucl. Chem. 245 (2000) 249-254

[23] Horwitz E.P., Chiarizia R., Dietz M.L., A novel strontium-selective extraction chromatographic resin, Solvent Extr. Ion Exch. 10 (1992) 313-336.

[24] International Atomic Energy Agency, Measurement of radionuclides in food and the environment, a Guidebook, Tech. Rep. Ser. 295 (1986) 70-91.

[25] Jeter W.H., Grob B., Determination of radiostrontium in milk using an extraction chromatography column, Radioact. Radiochem. 5 (1994) 8-17.

[26] Kimura T., Iwashima K., Ishimori T., Hamada T., Separation of strontium-89 and 90 from calcium in milk with a macrocyclic ether, Anal. Chem. 51 (1979) 1013-1016.

[27] Kirchmann R., Rétrospective des études sur la décontamination du lait et la répartition des produits de fission majeurs dans les dérivés, Seminary, Radioactivity transfer during food processing and culinary preparation, Gembloux, Belgique, 1989, pp. 231-249.

[28] Lamb J.D., Nordmeyer F.R., Drake P.A., Elder M.P., Miles R.W., Lash R.P., Ion chromatographic separation for analysis of radiostrontium in nuclear reprocessing solutions of high ionic strength, J. Radioanal. Nucl. Chem. 134 (1989) 317-331.

[29] Macasek F., Gerhart P., Distribution and speciation of cesium, strontium and europium in the aqueous two phase system milk- 
pectin, J. Radioanal. Nucl. Chem. 186 (1994) 87-95.

[30] Migikowsky B.B., Radioisotopes and environmental circumstances reduction of the hazard in the food chain, in: Caldecott R.S., Snyder L.A. (Eds.), Symposium on Radioisotope in the biosphere, University of Minnesota, USA, 1960, pp. 293-305.

[31] Mikulaj V., Svec V., Radiochemical analysis of strontium-90 in milk, soil and plants by solvent extraction, J. Radioanal. Nucl. Chem. 175 (1993) 317-324.

[32] Noshkin V.E., Mott N.S., Separation of strontium from large amounts of calcium, with application to radiostrontium analysis, Talanta 14 (1967) 45-51.

[33] Ovarec J., Navarcik I., Determination of ${ }^{137} \mathrm{Cs}$ and ${ }^{90} \mathrm{Sr}$ in milk by the static method with the ion exchanger, J. Radioanal. Nucl. Chem. 121 (1988) 331-335.

[34] Paasikallio A., Rantavaara A., Sippola J., The transfer of cesium-137 and strontium-90 from soil to food crops after the Chernobyl accident, Sci. Total Environ. 155 (1994) 109-124.

[35] Passo Jr C.J., Cook G.T., Handbook of environmental liquid scintillation spectrometry, Packard a Canberra Company, Meriden, USA, section IV (1994) 9-1-9-10.

[36] Piltingsrud H.V., Stencel J.R., Determination of strontium ${ }^{90} \mathrm{Y},{ }^{90} \mathrm{Sr}$ and ${ }^{89} \mathrm{Sr}$ in sample by use of liquid scintillation beta spectroscopy, Health Phys. 23 (1972) 121-122.

[37] Randolph R.R., Determination of strontium 90 and strontium 89 by Cerenkov and liquid scintillation counting, Appl. Radiat. Isotopes 26 (1975) 9-16.

[38] Shabana E.I., Al-Hussan K.A., Al-Jaseem Q.K., Adaptation of radioanalytical method for strontium 90 to different kinds of environmental samples and its application for the investigation of some samples in the Riyadh region, J. Radioanal. Nucl. Chem. 212 (1995) 229-240.

[39] Stella R., Ganzerli Valentini M.T., Maggi L., Ion exchange chromatography on a new form of tin dioxide for the isolation of strontium radioisotopes from fission products: an application to milk samples, Appl. Radiat. Isotopes 41 (1990) 905-908.

[40] Stella R., Ganzerli Valentini M.T., Maggi L., Determination of ${ }^{90} \mathrm{Sr}$ in milk by using two inorganic exchangers, Appl. Radiat. Isotopes 44 (1993) 1093-1096.

[41] Sutherland J.K., A spreadsheet method for ${ }^{90} \mathrm{Sr}$ and ${ }^{89} \mathrm{Sr}$ interpretation, Health Phys. 54 (1988) 69-72.
[42] Tait D., Wiechen A., Improvements to a rapid method for separating strontium from liquid milk by treatment with a chelating resin and crown ethers, J. Radioanal. Nucl. Chem. 159 (1992) 239-247.

[43] Tait D., Wiechen A., Haase G., Binding of Sr from milk by solid phase extraction with cryptand C222 sorbed on silica gel, cation exchange, chelating or adsorbent resins for simplified ${ }^{90} \mathrm{Sr}$ analysis, Sci. Total Environ. 173/174 (1995) 159-167.

[44] Tait D., Haase G., Wiechen A., Rapid and efficient separation of strontium from liquid milk with a cation exchange resin Dowex 50WX8 treated with cryptand 222 , J. Radioanal. Nucl. Chem. 226 (1997) 225-228.

[45] Tait D., Haase G., Wiechen A., A fast method for the determination of $\mathrm{Sr}-90$ in liquid milk by solid phase extraction with cryptand 222 on cation exchange resin, Kerntechnik 62 (1997) 96-98.

[46] Tait D., Haase G., Wiechen A., Use of a single strontium binding resin in a batch process followed by elution and precipitation of $\mathrm{SrCO}_{3}$ for the efficient analysis of ${ }^{89} \mathrm{Sr}$ and ${ }^{90} \mathrm{Sr}$ in liquid milk, Environmental radiochemical Analysis, Special Publication, Newton G.W.A. (Ed.), Royal Society of Chemistry, 234 (1999) 192-200.

[47] Thomas C.W., Determination of strontium90 in milk, Health Phys. 8 (1962) 407-415.

[48] Twardock A.R., Prinz W.H., Comar C.L., The state of calcium and strontium in goat's milk, Arch. Biochem. Biophys. 89 (1960) 309-312.

[49] Vaney B., Friedli C., Geering J.J., Lerch P., Rapid trace determination of radiostrontium in milk and drinking water, J. Radioanal. Nucl. Chem. 134 (1989) 87-95.

[50] Walstra P., Jenness R., Dairy Chemistry and Physics, Wiley-Interscience Publication, John Wiley \& Sons, New York, USA, 1984.

[51] Wendt K., Kratz J.V., Lantzsch J., Müller P., Nörtershäuser W., Seibert A., Trautman N., Waldek A., Zimmer K., Rapid ultratrace determination of ${ }^{89,90} \mathrm{Sr}$ in environmental samples by collinear laser resonance ionisation spectrometry, Kerntechnik 62 (1997) 81-84.

[52] Wilken R.D., Joshi S.R., Rapid methods for determining ${ }^{90} \mathrm{Sr},{ }^{89} \mathrm{Sr}$ and ${ }^{90} \mathrm{Y}$ in environmental samples: a survey, Radioact. Radiochem. 2 (1991) 14-27.

[53] Wong N.P., Jenness R., Keeney M., Marth E.H., Fundamentals of Dairy Chemistry, 3rd edn., Van Nostrand Reinhold, New York, USA, 1988. 